\title{
Spectroscopic and Transient Kinetic Studies of Site Requirements in Iron-Catalyzed Fischer-Tropsch Synthesis
}

\author{
Senzi Li, ${ }^{\dagger}$ Weiping Ding, $, ", *$ George D. Meitzner, ${ }^{\S}$ and Enrique Iglesia* ${ }^{* \dagger}$ \\ Department of Chemical Engineering, University of California, Berkeley, California 94720
}

Received: May 16, 2001; In Final Form: October 15, 2001

\begin{abstract}
The structure, reduction/carburization, and catalytic performance of $\mathrm{K}$ - and $\mathrm{Cu}$-promoted $\mathrm{Fe}_{2} \mathrm{O}_{3}$ during initial contact with synthesis gas were examined by combining kinetic analysis of the initial stages of FischerTropsch synthesis (FTS) with X-ray absorption spectroscopy. Oxygen removal initially occurs without FTS reactions as $\mathrm{Fe}_{2} \mathrm{O}_{3}$ is reduced to inactive oxygen-deficient $\mathrm{Fe}_{2} \mathrm{O}_{3}$ species. Hydrocarbon synthesis reactions become detectable only as $\mathrm{Fe}_{3} \mathrm{O}_{4}$ forms and rapidly converts to $\mathrm{FeC}_{x}$. FTS reactions require only the incipient conversion of the surface layers to a dynamic and active surface phase, which consists of FeC $\mathrm{C}_{x}$ with steadystate surface coverages of vacancies, formed via oxygen and carbon removal during the formation of monomers, $\mathrm{CO}_{2}$, and $\mathrm{H}_{2} \mathrm{O}$. Such surfaces tend to respond to changes in the contacting gas phase within turnover times by changing the relative surface concentration of carbon, oxygen, $\mathrm{CO}$, and hydrogen. The catalytic behavior of these dynamic surfaces is largely independent of the carbide or oxide nature of the particle cores. These findings, combined with the rapid formation and interconversion of $\mathrm{Fe}_{3} \mathrm{O}_{4}$ and $\mathrm{FeC}_{x}$ within characteristic FTS turnover times, make the definite assignment of FTS activity to either phase neither appropriate nor kinetically rigorous. The presence of $\mathrm{K}$ and $\mathrm{Cu}$ increases FTS rates, and the steady-state extent of carburization by providing nucleation sites for the formation of smaller $\mathrm{FeC}_{x}$ crystallites. These smaller active domains lead, in turn, to shorter diffusion paths and to a larger number of sites for $\mathrm{CO}$ adsorption/dissociation and for FTS reactions. These structural promotion effects of $\mathrm{K}$ and $\mathrm{Cu}$ were consistent with reaction rates, $\mathrm{X}$-ray absorption spectra, and site density measured on promoted and unpromoted catalysts as a function of time in contact with synthesis gas.
\end{abstract}

\section{Introduction}

Precipitated $\mathrm{Fe}-\mathrm{Zn}$ oxide precursors promoted with $\mathrm{K}$ and $\mathrm{Cu}$ form active and selective Fischer-Tropsch synthesis catalysts ${ }^{1}$ after activation processes that lead to complex mixtures of reduced $\mathrm{Fe}$ compounds. The structure of these catalyst precursors and their reduction in $\mathrm{H}_{2}$ and carburization in $\mathrm{CO}$ were previously examined with specific emphasis on the role of the $\mathrm{K}$ and $\mathrm{Cu}$ promoters on the structure and transformations of these materials. ${ }^{2}$

The objective of the present study is to characterize these structural changes, the stoichiometry of the active phases formed, and their catalytic behavior as Fischer-Tropsch synthesis reactions occur. The reduction and carburization kinetics in $\mathrm{H}_{2}-$ $\mathrm{CO}$ mixtures, the rate of hydrocarbon synthesis reactions, and the density of active sites on $\mathrm{K} / \mathrm{Cu}$-promoted $\mathrm{Fe}_{2} \mathrm{O}_{3}$ were probed using a combination of isothermal rate transients and X-ray absorption spectroscopy during the initial contact of these samples with synthesis gas. The products formed during initial exposure to synthesis gas were detected using on-line mass spectrometric analysis combined with deconvolution methods required in order to unravel the concentrations of individual components from complex fragmentation patterns of multicomponent hydrocarbon mixtures. These methods allowed concur-

* To whom correspondence should be addressed. E-mail: iglesia@ cchem.berkeley.edu.

${ }^{\dagger}$ Department of Chemical Engineering, University of California, Berkeley.

$\doteqdot$ Current Address: Department of Chemistry, Nanjing University, Nanjing, China.

${ }^{\S}$ Edge Analytical, Inc., Middleton, WI 53562. rent measurements of the amount of oxygen removed from $\mathrm{Fe}_{2} \mathrm{O}_{3}$ precursors and of the effect of oxygen-deficiency on FTS rates. X-ray absorption spectroscopic measurements were carried out in parallel at identical reaction conditions in order to detect the evolution of $\mathrm{Fe}, \mathrm{FeO}_{y}$, and $\mathrm{FeC}_{x}$ structures during FTS. These studies were combined with measurements of the density of $\mathrm{CO}$ binding sites using recently developed protocols ${ }^{3}$ and of BET surface areas after quenching samples during FTS reactions.

The observed correlation between the transient evolution of the catalyst structure and of the reaction products, showed that the surface areas of particles with $\mathrm{Fe}_{3} \mathrm{O}_{4}$ or $\mathrm{FeC}_{x}$ composition in near surface layers controls FTS rates, irrespective of the chemical nature of the residual oxide or carbide cores. These findings, combined with site density values inferred from surface area and $\mathrm{CO}$ chemisorption, show that $\mathrm{K}$ and $\mathrm{Cu}$ provide sites for the rapid nucleation of a high density of $\mathrm{Fe}_{3} \mathrm{O}_{4}$ and $\mathrm{FeC}_{x}$ clusters, a process that leads to the ultimate formation of smaller and more extensively carburized catalytic structures, with a higher surface area and a larger number of active sites for FTS reactions.

In these studies, structural promoters, such as $\mathrm{ZnO}^{1,4}$ or $\mathrm{SiO}_{2},{ }^{5,6}$ were excluded from $\mathrm{Fe}$ oxide precursors in order to discern the specific effects of $\mathrm{Cu}$ and $\mathrm{K}$, without the structural complexity introduced by additional promoters. These structural promoters increase the surface areas of Fe oxide precursors, without detectable changes in the nature of the active sites or in chain growth pathways. ${ }^{2} \mathrm{ZnO}$ increases surface areas but also forms a $\mathrm{ZnFe}_{2} \mathrm{O}_{4}$ phase, which does not reduce or carburize 
during FTS, as shown by Zn K-edge X-ray absorption spectroscopy. ${ }^{8}$ The behavior of $\mathrm{Fe}$ oxides promoted by $\mathrm{ZnO}$ has been reported separately. ${ }^{9}$ The exclusion of $\mathrm{Zn}$ from the $\mathrm{Fe}-$ $\mathrm{K}-\mathrm{Cu}$ oxides used here does not influence the nature of the structural transformations or the way in which they are influenced by $\mathrm{Cu}$ or $\mathrm{K}$.

\section{Experimental Section}

1. Synthesis of $\mathbf{F e}-\mathbf{K}-\mathbf{C u}$ Oxide Precursors. $\mathrm{Fe}_{2} \mathrm{O}_{3}$ precursors were prepared by precipitation from aqueous solutions of $\mathrm{Fe}\left(\mathrm{NO}_{3}\right)_{3}$ (Aldrich, $>99.9 \%, 3.0 \mathrm{M}$ ). These solutions were added at $0.033 \mathrm{~cm}^{3} / \mathrm{s}$ into a continuously stirred flask maintained at $353 \mathrm{~K}$ and initially containing deionized water $\left(50 \mathrm{~cm}^{3}\right)$. Ammonium carbonate $\left[\left(\mathrm{NH}_{4}\right)_{2} \mathrm{CO}_{3}\right.$; Aldrich, $\left.99.9 \%, 1 \mathrm{M}\right]$ was added separately into this flask; its flow rate was adjusted in order to maintain the slurry $\mathrm{pH}$ at $7.0 \pm 0.1$ (pH Meter; Omega, PHB-62). The resulting precipitates $(\sim 20 \mathrm{~g})$ were washed five times with deionized water $(1 \mathrm{li} / \mathrm{g})$ and dried in ambient air at $393 \mathrm{~K}$ overnight. The dry powders were treated in flowing dry air $\left(\sim 500 \mathrm{~cm}^{3} / \mathrm{h} \cdot\right.$ g-cat.) at $623 \mathrm{~K}$ for $1 \mathrm{~h}$ and then impregnated to incipient wetness with aqueous solutions of $\mathrm{K}_{2} \mathrm{CO}_{3}$ (Aldrich, $99.99 \%, 0.16 \mathrm{M}$ ) and/or $\mathrm{Cu}\left(\mathrm{NO}_{3}\right)_{2}$ (Aldrich, 99.99\%, $0.16 \mathrm{M}$ ) to give the desired $\mathrm{K} / \mathrm{Fe}$ and $\mathrm{Cu} / \mathrm{Fe}$ atomic ratios $(\mathrm{K} / \mathrm{Fe}=0.02$, $\mathrm{Cu} / \mathrm{Fe}=0.01)$. The samples were dried again in ambient air at $373 \mathrm{~K}$ overnight and treated in dry air at $673 \mathrm{~K}$ for $4 \mathrm{~h}$; this treatment leads to the decomposition of nitrates, hydroxides and carbonates, except $\mathrm{K}_{2} \mathrm{CO}_{3} .{ }^{10}$ The resulting catalyst precursors contained $\mathrm{CuO}, \mathrm{Fe}_{2} \mathrm{O}_{3}$, and $\mathrm{K}_{2} \mathrm{CO}_{3}$ and they are designated as $\mathrm{Fe}_{2} \mathrm{O}_{3}, \mathrm{Fe}_{2} \mathrm{O}_{3}-\mathrm{Cu}, \mathrm{Fe}_{2} \mathrm{O}_{3}-\mathrm{K}$, and $\mathrm{Fe}_{2} \mathrm{O}_{3}-\mathrm{K}-\mathrm{Cu}$. They were uniaxially pressed into pellets at $440 \mathrm{MPa}$, and sieved to retain particles with $100-180 \mu \mathrm{m}$ diameter, which were used in all catalytic and characterization studies.

2. Structural and Chemical Characterization of Precursors and Catalysts. 2.1. Isothermal Transient Measurements of Fischer-Tropsch Synthesis Rates. Initial rates of reduction and carburization of $\mathrm{Fe}$ oxide precursors and their residual oxygen content during FTS were measured using on-line mass spectrometry (Leybold Inficon, Transpector Series) as a function of time of contact with synthesis gas. Samples $(0.2 \mathrm{~g})$ were held within a quartz microreactor and diluted with graphite $(0.5$ g, Alfa AESAR, 99.998\%, 100 180 $\mu \mathrm{m}$, BET surface area < $1 \mathrm{~m}^{2} / \mathrm{g}$ ) to minimize temperature gradients during FTS and to reproduce the exact details of the X-ray absorption studies conducted in parallel, in which graphite was used as a diluent in order to minimize absorption artifacts. The inertness of graphite during FTS was confirmed by the absence of $\mathrm{CO}, \mathrm{CO}_{2}$, or any hydrocarbons even at $873 \mathrm{~K}$ in flowing $\mathrm{H}_{2}$. These products could form via hydrogenation of graphite or of $\mathrm{CO}_{x}$ formed by solid-state reactions of carbon with lattice oxygen in Fe oxide precursors or intermediates. Samples were treated in $\mathrm{He}(0.268 \mathrm{~mol} / \mathrm{h})$ at $573 \mathrm{~K}$ for $0.2 \mathrm{~h}$, cooled to $523 \mathrm{~K}$, and then exposed to synthesis gas $\left(\mathrm{H}_{2} / \mathrm{CO} / \mathrm{Ar}=2 / 1 / 2,100 \mathrm{kPa}\right.$, $0.268 \mathrm{~mol} / \mathrm{h}$ ). The transient evolution of hydrocarbons formed in FTS reactions and of reduction-carburization products $\left(\mathrm{CH}_{4}\right.$, $\mathrm{H}_{2} \mathrm{O}$, and $\mathrm{CO}_{2}$, etc.) was measured at $523 \mathrm{~K}$ as a function of time using on-line mass spectrometry (Leybold Inficon, Transpector Series, $1.02 \mathrm{~s} / \mathrm{scan}$ at $32 \mathrm{~ms}$ dwell time).

These isothermal transient measurements were also carried out on $\mathrm{Fe}_{3} \mathrm{O}_{4}$ and $\mathrm{FeC}_{x}$ (a mixture of $\mathrm{Fe}_{2.5} \mathrm{C}$ and $\mathrm{Fe}_{3} \mathrm{C}$ ) samples prepared by temperature-programmed reactions of $\mathrm{Fe}_{2} \mathrm{O}_{3}$ in $\mathrm{H}_{2}$ or $\mathrm{CO}$, respectively. The synthetic procedures used to prepare these materials involved interrupted thermal treatments of $\mathrm{Fe}_{2} \mathrm{O}_{3}$ precursors and verification of the structural purity of the phases formed by X-ray diffraction. These $\mathrm{Fe}_{3} \mathrm{O}_{4}$ and $\mathrm{FeC}_{x}$ powders were prepared from $\mathrm{Cu}$-containing $\mathrm{Fe}_{2} \mathrm{O}_{3}$ precursors, because $\mathrm{Cu}$ leads to the easier isolation of pure $\mathrm{Fe}_{3} \mathrm{O}_{4}$, without residual $\mathrm{Fe}_{2} \mathrm{O}_{3}$ and without the formation of $\mathrm{FeO}$ or Fe. The $\mathrm{Fe}_{2} \mathrm{O}_{3}-\mathrm{Cu}$ precursor $(0.2 \mathrm{~g}, \mathrm{Cu} / \mathrm{Fe}=0.01)$ was treated in $20 \% \mathrm{H}_{2} / \mathrm{Ar}(0.268$ $\mathrm{mol} / \mathrm{h}$ ) as the temperature was increased to $533 \mathrm{~K}$ at $0.083 \mathrm{~K} / \mathrm{s}$; this procedure led to the stoichiometric reduction of $\mathrm{Fe}_{2} \mathrm{O}_{3}-$ $\mathrm{CuO}$ to pure $\mathrm{Fe}_{3} \mathrm{O}_{4}$ and $\mathrm{Cu}$ metal. This was confirmed by the oxygen removal stoichiometry and by $\mathrm{X}$-ray diffraction. $\mathrm{FeC}_{x^{-}}$ $\mathrm{Cu}$ was prepared by treating $\mathrm{Fe}_{2} \mathrm{O}_{3}-\mathrm{CuO}(0.2 \mathrm{~g}, \mathrm{Cu} / \mathrm{Fe}=0.01)$ precursors in $20 \% \mathrm{CO} / \mathrm{Ar}(0.268 \mathrm{~mol} / \mathrm{h})$, whereas increasing the temperature to $673 \mathrm{~K}$ at $0.083 \mathrm{~K} / \mathrm{s}$. The slow ramping rate was used in order to accurately interrupt the structural transformation before deposition of noncarbidic carbon. X-ray diffraction measurements confirmed that prereduced samples consisted of pure $\mathrm{Fe}_{3} \mathrm{O}_{4}$, whereas carburized samples contained a mixture of $\mathrm{Fe}_{2.5} \mathrm{C}$ and $\mathrm{Fe}_{3} \mathrm{C}$, which we denote here as $\mathrm{FeC}_{x}$. Pre-reduced and pre-carburized samples were cooled to $523 \mathrm{~K}$ in $\mathrm{He}(0.268 \mathrm{~mol} / \mathrm{h})$ and exposed to synthesis gas for isothermal transient measurements without intervening exposure to ambient air.

2.2. X-ray Absorption Spectroscopy (XAS) Measurements. $\mathrm{X}$-ray absorption spectra were collected at the Fe K-edge using a wiggler side-station beamline (4-1) at the Stanford Synchrotron Radiation Laboratory (SSRL). The storage ring was operated at 30-100 $\mathrm{mA}$ and $3.0 \mathrm{GeV}$ during the measurements. Two $\mathrm{Si}(111)$ crystals detuned by $20 \%$ in order to reject harmonics were used in the monochromator. The most restrictive aperture along the beam path was a $0.2 \times 12 \mathrm{~mm}$ slit, which limited the energy resolution to $\sim 1 \mathrm{eV}$ at the Fe K-edge (7.112 $\mathrm{keV}){ }^{11,12}$ The spectra were analyzed using WinXAS (version 1.2). ${ }^{13}$ Principal component analysis ${ }^{14}$ and linear combination methods ${ }^{15}$ were used in order to determine the structures present in each sample from spectral features in the near-edge region (7.090-7.240 keV). All samples were diluted to 15 wt $\% \mathrm{Fe}$ using graphite powder (Alfa AESAR, 99.9995\%, BET surface area $S_{\mathrm{g}}<1 \mathrm{~m}^{2} / \mathrm{g}$ ), pressed at $300 \mathrm{MPa}$, sieved to retain $100-$ $180 \mu \mathrm{m}$ particles, and placed within a quartz X-ray absorption capillary cell. ${ }^{3}$ After exposure to synthesis gas $\left(\mathrm{H}_{2} / \mathrm{CO}=2\right)$ for a given period of time at $523 \mathrm{~K}$, He was used to flush the samples, which were cooled to ambient temperature in $10 \mathrm{~s}$ by removing the surrounding heated $\mathrm{Cu}$ block. X-ray absorption spectra were measured in flowing $\mathrm{He}$ at ambient temperature.

2.3. CO Chemisorption and Surface Area Measurements. CO chemisorption uptakes were measured after transient experiments in synthesis gas at $523 \mathrm{~K}$ for $1 \mathrm{~h}$ and a subsequent $\mathrm{He}$ purge $(0.268 \mathrm{~mol} / \mathrm{h})$ at $523 \mathrm{~K}$ for $1 \mathrm{~h}$; the purge step was used in order to remove reversibly adsorbed species. CO chemisorption and BET surface area measurements were then carried out after cooling to ambient temperature. The details of these $\mathrm{CO}$ chemisorption procedures have been described elsewhere. ${ }^{3} \mathrm{BET}$ surface area measurements were carried out after FTS reaction at $523 \mathrm{~K}$ for $1 \mathrm{~h}$, quenching to ambient temperature, and passivation of the samples in flowing $1 \% \mathrm{O}_{2} / \mathrm{He}$ at room temperature. $\mathrm{N}_{2}$ physisorption measurements were performed at its normal boiling point (77 K) using an Autosorb 6 system (Quantachrome, Inc.). Surface areas were calculated using the BET method.

\section{Results and Discussion}

Product Evolution and X-ray Absorption Measurements during Isothermal Transients of $\mathrm{Fe}_{2} \mathrm{O}_{3}$ in Synthesis Gas. Figure 1 shows the rates of formation of $\mathrm{CH}_{4}, \mathrm{H}_{2} \mathrm{O}$, and $\mathrm{CO}_{2}$ during initial contact of $\mathrm{Fe}_{2} \mathrm{O}_{3}$ with $\mathrm{H}_{2} / \mathrm{CO}$ at $523 \mathrm{~K}$. During the first $140 \mathrm{~s}$, lattice oxygen was removed from $\mathrm{Fe}_{2} \mathrm{O}_{3}$ as $\mathrm{CO}_{2}$ 


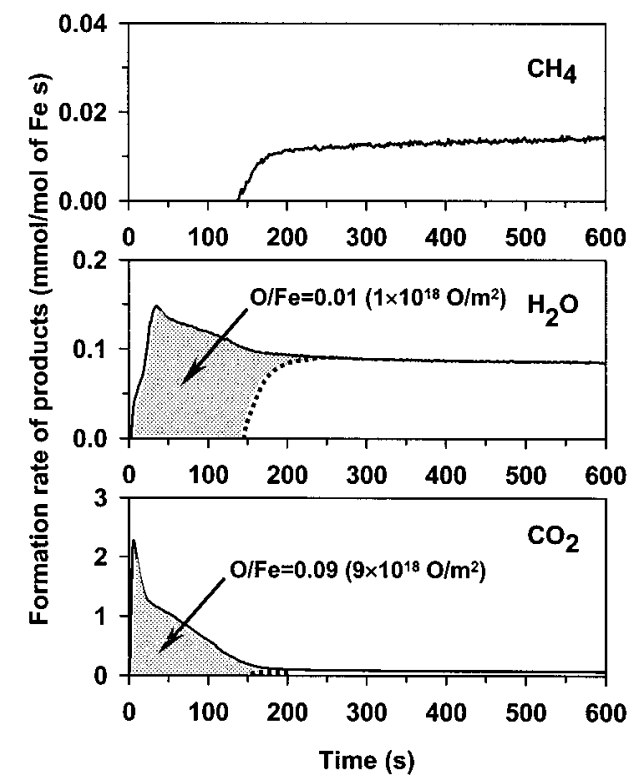

Figure 1. Rates of formation of $\mathrm{CH}_{4}, \mathrm{H}_{2} \mathrm{O}$, and $\mathrm{CO}_{2}$ as a function of time during contact with synthesis gas at $523 \mathrm{~K}$ for precipitated $\mathrm{Fe}_{2} \mathrm{O}_{3}$ ( $0.2 \mathrm{~g}$ sample; $\mathrm{H}_{2} / \mathrm{CO}=2$, synthesis gas flow rate $=0.268 \mathrm{~mol} / \mathrm{h}$ ). The shaded areas in the formation of $\mathrm{H}_{2} \mathrm{O}$ and $\mathrm{CO}_{2}$ are their respective amounts formed from the reduction of $\mathrm{Fe}$ oxides upon exposure to synthesis gas; the dashed lines are their expected values from subsequent FTS reactions.

and $\mathrm{H}_{2} \mathrm{O}$, without the concurrent formation of $\mathrm{CH}_{4}$. Here, $\mathrm{CH}_{4}$ formation rates are used as a surrogate measure of hydrocarbon synthesis rates, because $\mathrm{CH}_{4}$ concentrations can be measured accurately and they change with time in parallel with those of heavier hydrocarbon products. $\mathrm{CH}_{4}$ formation became detectable after an induction period and it rapidly reached steady-state $(<200 \mathrm{~s})$. Thus, the formation of the active sites required for FTS reactions is rapid and it requires the initial removal of only a very small amount of lattice oxygen $(\sim 7 \%)$ from $\mathrm{Fe}_{2} \mathrm{O}_{3}$. It appears that the number of sites and the surface area available for FTS reactions, as well as the surface composition of the active phase reach near steady-state values after the removal of only a few equivalent monolayers of lattice oxygen from $\mathrm{Fe}_{2} \mathrm{O}_{3}$ precursors.

The lattice oxygen atoms are removed from $\mathrm{Fe}_{2} \mathrm{O}_{3}$ precursors by $\mathrm{H}_{2}$ to form $\mathrm{H}_{2} \mathrm{O}$ or by $\mathrm{CO}$ to form $\mathrm{CO}_{2}$. The $\mathrm{O} / \mathrm{Fe}$ atomic ratios for the lattice oxygen removed as $\mathrm{H}_{2} \mathrm{O}$ and $\mathrm{CO}_{2}$ are 0.01 and 0.09 , respectively (the shaded area under the initial reduction peaks in Figure 1), which corresponds to a total sum of oxygen removed relative to $\mathrm{Fe}(\mathrm{O} / \mathrm{Fe})$ of 0.1 . This corresponds to 1.5 $\times 10^{19} \mathrm{O}$-atom $/ \mathrm{m}^{2}$ for the BET surface area of these precursor oxides $\left(\sim 50 \mathrm{~m}^{2} / \mathrm{g}\right)$. This value is similar to the oxygen surface density expected for oxygen-exposed metal oxide surfaces $\left(\sim 10^{19} \mathrm{O}\right.$-atom $\left./ \mathrm{m}^{2}\right)$. CO appears to be the preferred reductant and $\mathrm{CO}_{2}$ the predominant product for pure $\mathrm{Fe}_{2} \mathrm{O}_{3}$. Steady-state FTS reaction rates required the removal of some lattice oxygen from stoichiometric $\mathrm{Fe}_{2} \mathrm{O}_{3}$, which appears not to be able to catalyze FTS reactions without some reduction. Active sites require the formation of oxygen-deficient species $\left(\mathrm{Fe}_{2} \mathrm{O}_{3-x}\right.$, $x \sim 0.2$ ). These stoichiometries, however, clearly represent average values for $\mathrm{Fe}_{2} \mathrm{O}_{3}$ crystallites, and they reflect a substantially unreduced $\mathrm{Fe}_{2} \mathrm{O}_{3}$ core surrounded by more extensively reduced and carburized regions near particle surfaces. FTS rates reached steady-state values after structural changes in only a few outer layers of the $\mathrm{Fe}_{2} \mathrm{O}_{3}$ precursor crystallites.

These transient studies are unable to detect the additional reduction and carburization events that occur after attaining

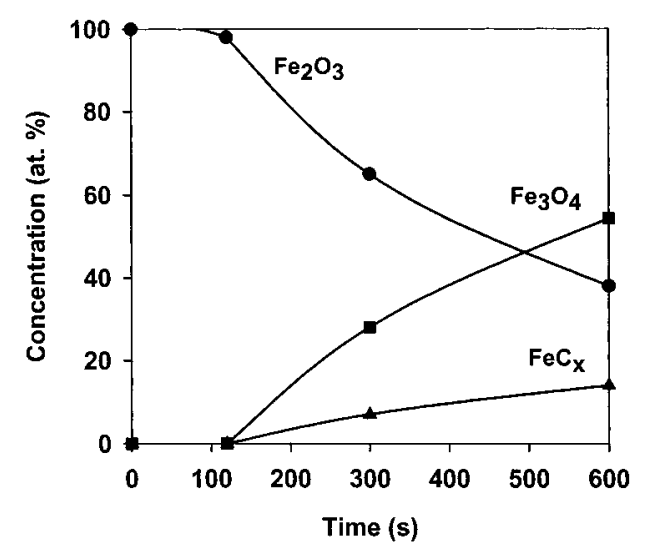

Figure 2. Structural evolution of $\mathrm{Fe}_{2} \mathrm{O}_{3}$ with time on stream after

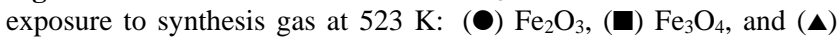
$\mathrm{FeC}_{x}\left(1 \mathrm{mg}\right.$ sample; $\mathrm{H}_{2} / \mathrm{CO}=2$, synthesis gas flow rate $=107 \mathrm{~mol} /$ mol of Fe h).

steady-state FTS rates because the amounts of $\mathrm{H}_{2} \mathrm{O}$ and $\mathrm{CO}_{2}$ formed in FTS reactions become significantly larger than those formed via the gradual removal of additional lattice oxygen from less accessible internal regions within $\mathrm{Fe}_{2} \mathrm{O}_{3}$ crystallites. To detect structural changes occurring over these longer time scales, $\mathrm{X}$-absorption spectroscopy was used to measure the structural evolution of $\mathrm{Fe}_{2} \mathrm{O}_{3}$ after exposure to synthesis gas at FTS reaction conditions $\left(523 \mathrm{~K}, \mathrm{H}_{2} / \mathrm{CO}=2\right)$ for various periods of times.

Principal component analysis methods ${ }^{14}$ identified three components, $\mathrm{Fe}_{2} \mathrm{O}_{3}, \mathrm{Fe}_{3} \mathrm{O}_{4}$, and $\mathrm{FeC}_{x}$, as the only species that changed in concentration as the near-edge $\mathrm{X}$-ray absorption spectra changed with time on stream. The two Fe carbide phases $\left(\mathrm{Fe}_{3} \mathrm{C}\right.$ and $\mathrm{Fe}_{2.5} \mathrm{C}$ ) cannot be distinguished by their near-edge spectra and they are reported as a lump and denoted as $\mathrm{FeC}_{x}$. The spectra of samples were described as linear combinations of the near-edge spectra of the three standard compounds identified by principal component analysis. ${ }^{15}$ The detailed analysis procedure has been described elsewhere ${ }^{3}$. Figure 2 shows the change in the concentrations of the $\mathrm{Fe}_{2} \mathrm{O}_{3}, \mathrm{Fe}_{3} \mathrm{O}_{4}$, and $\mathrm{FeC}_{x}$ phases as a function of the time elapsed after initial contact with synthesis gas at $523 \mathrm{~K}$. Neither $\mathrm{Fe}_{3} \mathrm{O}_{4}$ nor $\mathrm{FeC}_{x}$ components were detected during the induction period. After the induction period, $\mathrm{Fe}_{3} \mathrm{O}_{4}$ and $\mathrm{FeC}_{x}$ formed concurrently and the extent of carburization increased gradually with time. Thus, it appears that the $\mathrm{O}$-deficient $\mathrm{Fe}_{2} \mathrm{O}_{3}$ initially formed undergoes structural changes to form species with the local coordination of $\mathrm{Fe}_{3} \mathrm{O}_{4}$ only when the density of oxygen vacancies in $\mathrm{Fe}_{2} \mathrm{O}_{3}$ reaches a critical value, which destabilizes the $\mathrm{Fe}_{2} \mathrm{O}_{3}$ structure and leads to the nucleation of the $\mathrm{Fe}_{3} \mathrm{O}_{4}$ phase.

$\mathrm{Fe}_{3} \mathrm{O}_{4}$ was never detected without the concurrent presence of $\mathrm{FeC}_{x}$ during exposure to synthesis gas, suggesting that its subsequent conversion to $\mathrm{FeC}_{x}$ occurs at rates similar to its rate of formation from $\mathrm{Fe}_{2} \mathrm{O}_{3}$ in synthesis gas at $523 \mathrm{~K}$. The simultaneous appearance of $\mathrm{Fe}_{3} \mathrm{O}_{4}$ and $\mathrm{FeC}_{x}$ coincides with the detection of gas-phase hydrocarbon products, suggesting that $\mathrm{Fe}_{3} \mathrm{O}_{4}, \mathrm{FeC}_{x}$, or both, provide the required catalytic sites. As $\mathrm{Fe}_{3} \mathrm{O}_{4}$ continued to convert to $\mathrm{FeC}_{x}$, FTS reaction rates remained nearly constant, even as the structures changed markedly, suggesting that only a fraction of the Fe species, probably those near surfaces, are involved in FTS reactions and that they form rapidly during initial contact with synthesis gas. Clearly, the structure and composition of near-surface layers are more likely to influence catalytic turnovers than the structure of an inaccessible bulk; the easier access by reactants to near-surface regions also lead these regions to reach steady-state compositions 


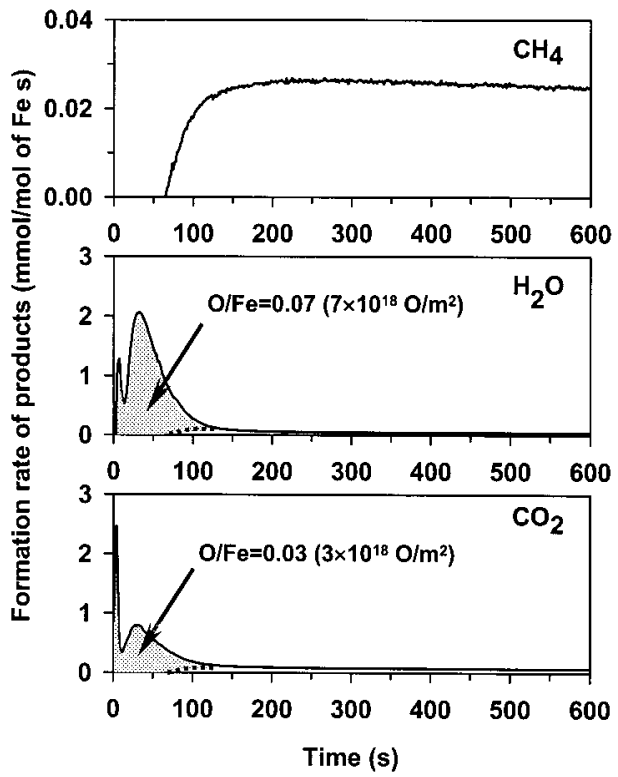

Figure 3. Rates of formation of $\mathrm{CH}_{4}, \mathrm{H}_{2} \mathrm{O}$, and $\mathrm{CO}_{2}$ as a function of time during contact with synthesis gas at $523 \mathrm{~K}$ for $\mathrm{Fe}_{2} \mathrm{O}_{3}-\mathrm{Cu}(0.2 \mathrm{~g}$ sample; $\mathrm{Cu} / \mathrm{Fe}=0.01 ; \mathrm{H}_{2} / \mathrm{CO}=2$, synthesis gas flow rate $=0.268$ $\mathrm{mol} / \mathrm{h}$ ). The shaded areas in the formation of $\mathrm{H}_{2} \mathrm{O}$ and $\mathrm{CO}_{2}$ are their respective amounts formed from the reduction of $\mathrm{Fe}$ oxides upon exposure to synthesis gas; the dashed lines are their expected values from subsequent FTS reactions.

and structures much more rapidly than particle cores, which are also probed by X-ray photons, but which are accessible only via bulk diffusion of oxygen and carbon. FTS reaction rates on such steady-state surfaces are not influenced by the residual presence of an $\mathrm{Fe}_{2} \mathrm{O}_{3}$ or $\mathrm{Fe}_{3} \mathrm{O}_{4}$ core within particles or by the gradual conversion of these cores to $\mathrm{FeC}_{x}$ during more extended contact with synthesis gas.

Product Evolution and X-ray Absorption Measurements during Exposure of $\mathrm{Fe}_{2} \mathrm{O}_{3}-\mathrm{Cu}$ to Synthesis Gas. Figure 3 shows the rates of lattice oxygen removal and of $\mathrm{CH}_{4}$ formation on $\mathrm{Fe}_{2} \mathrm{O}_{3}-\mathrm{Cu}(\mathrm{Cu} / \mathrm{Fe}=0.01)$ during initial exposure to synthesis gas at $523 \mathrm{~K}$. The transient evolution of products on $\mathrm{Fe}_{2} \mathrm{O}_{3}-\mathrm{Cu}$ resembles that observed on pure $\mathrm{Fe}_{2} \mathrm{O}_{3}$, except that the induction period is significantly shorter and lattice oxygen is predominately removed by $\mathrm{H}_{2}$ as $\mathrm{H}_{2} \mathrm{O}$, instead of by $\mathrm{CO}$. $\mathrm{CuO}$ reduces to $\mathrm{Cu}$ metal in $\mathrm{H}_{2}$ at $453 \mathrm{~K},{ }^{2}$ and the area under the sharp first peak in Figure 3 corresponds to the removal of all lattice oxygen atoms from $\mathrm{CuO}$ to form $\mathrm{Cu}$ metal. $\mathrm{Cu}$ appears to increase the rate of $\mathrm{Fe}_{2} \mathrm{O}_{3}$ reduction to $\mathrm{Fe}_{3} \mathrm{O}_{4}$ by providing $\mathrm{H}_{2}$ dissociation sites; consequently, a larger number of oxygen atoms are removed by $\mathrm{H}_{2}(\mathrm{O} / \mathrm{Fe}=0.07)$ as $\mathrm{H}_{2} \mathrm{O}$, than by $\mathrm{CO}$ $(\mathrm{O} / \mathrm{Fe}=0.03)$ as $\mathrm{CO}_{2}$ on $\mathrm{Fe}_{2} \mathrm{O}_{3}-\mathrm{Cu}$. The total number of oxygen atoms removed during the induction period required in order to reach steady-state FTS rates, however, was very similar to that on pure $\mathrm{Fe}_{2} \mathrm{O}_{3}$, even though the presence of $\mathrm{Cu}$ increased reduction rates and provided alternate reduction pathways. $\mathrm{CH}_{4}$ formation rates increased as oxygen was removed after the initial induction period, and then reached steady-state rates after $\sim 150$ $\mathrm{s}$. $\mathrm{Cu}$ increases the rate of oxygen removal and the rate of formation of active sites; as a result, $\mathrm{Cu}$ also decreases the time required in order to reach the catalytic steady-state. $\mathrm{Cu}$ leads to higher steady-state FTS reaction rates; even though both $\mathrm{Fe}_{2} \mathrm{O}_{3}$ and $\mathrm{Fe}_{2} \mathrm{O}_{3}-\mathrm{Cu}$ reached similar extents of reduction, as measured by the amount of oxygen removed during the induction period. $\mathrm{Cu}$ appears to lead to the formation of a higher density of active sites, a conclusion consistent with the measured number of $\mathrm{CO}$ binding sites after activation and FTS reactions on $\mathrm{Fe}_{2} \mathrm{O}_{3}$ and

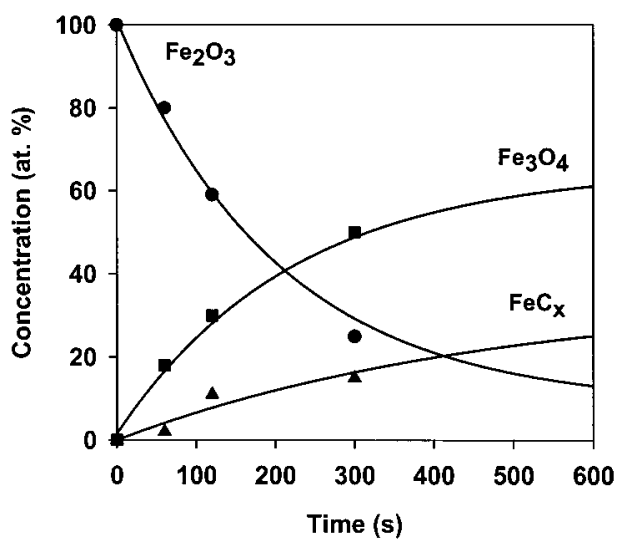

Figure 4. Structural evolution of $\mathrm{Fe}_{2} \mathrm{O}_{3}-\mathrm{Cu}$ with time on stream after exposure to synthesis gas at $523 \mathrm{~K}:(\bullet) \mathrm{Fe}_{2} \mathrm{O}_{3}$, (ロ) $\mathrm{Fe}_{3} \mathrm{O}_{4}$, and (ム) $\mathrm{FeC}_{x}\left(1 \mathrm{mg}\right.$ sample; $\mathrm{Cu} / \mathrm{Fe}=0.01 ; \mathrm{H}_{2} / \mathrm{CO}=2$, synthesis gas flow rate $=107 \mathrm{~mol} / \mathrm{mol}$ of $\mathrm{Fe} \mathrm{h}$ ).

$\mathrm{Fe}_{2} \mathrm{O}_{3}-\mathrm{Cu}$ samples, as discussed below. It appears that the formation of $\mathrm{Cu}$ metal crystallites on $\mathrm{Fe}_{2} \mathrm{O}_{3}$ crystallite surfaces during the early stages of reaction with synthesis gas leads to the rapid nucleation of a higher density of $\mathrm{Fe}_{3} \mathrm{O}_{4}$ and $\mathrm{FeC}_{x}$ crystallites. The resulting larger number of nuclei leads to the ultimate formation of smaller crystallites of either $\mathrm{Fe}_{3} \mathrm{O}_{4}$ or $\mathrm{FeC}_{x}$, to larger active surface areas, and to higher FTS rates.

Figure 4 shows the results of a linear combination analysis of the near-edge spectra measured during exposure of $\mathrm{Fe}_{2} \mathrm{O}_{3}-$ $\mathrm{Cu}$ to synthesis gas at $523 \mathrm{~K} . \mathrm{Fe}_{2} \mathrm{O}_{3}-\mathrm{Cu}$ underwent sequential structural changes very similar to those detected in $\mathrm{Fe}_{2} \mathrm{O}_{3}$ (Figure 2). $\mathrm{Fe}_{2} \mathrm{O}_{3}$ disappeared more rapidly when $\mathrm{Cu}$ was present; $\mathrm{Fe}_{3} \mathrm{O}_{4}$ and $\mathrm{FeC}_{x}$ were detected concurrently at shorter contact times in $\mathrm{Fe}_{2} \mathrm{O}_{3}-\mathrm{Cu}$ than in $\mathrm{Fe}_{2} \mathrm{O}_{3}$. The extent of reduction and carburization increased with time. As also shown by the $\mathrm{CH}_{4}$ evolution isothermal transients, the induction period required to form $\mathrm{Fe}_{3} \mathrm{O}_{4}$ and $\mathrm{FeC}_{x}$ was significantly shorter on the $\mathrm{Cu}$ containing sample. Also, the extent of carburization was higher on $\mathrm{Fe}_{2} \mathrm{O}_{3}-\mathrm{Cu}$ samples than on $\mathrm{Fe}_{2} \mathrm{O}_{3}$ for a given time in contact with synthesis gas. A reasonable explanation for the faster and more complete carburization of $\mathrm{Cu}$-containing Fe oxides is the presence of smaller crystallites, because the rate of carburization of metal oxides is typically controlled by oxygen diffusion from the oxide core to its surface. ${ }^{16}$ The presence of $\mathrm{Cu}$ metal at particle surfaces cannot possibly influence rates of oxygen diffusion through an oxide core or a carbide shell. For a given crystallite size, $\mathrm{Fe}_{2} \mathrm{O}_{3}$ and $\mathrm{Fe}_{2} \mathrm{O}_{3}-\mathrm{Cu}$ should show similar rates and extents of carburization. The apparently conflicting X-ray absorption data (Figures 2 and 4), which shows higher rates and extents of carburization on $\mathrm{Cu}$-containing catalyst than on unpromoted $\mathrm{Fe}_{2} \mathrm{O}_{3}$, are reconciled by this proposal, which suggests that $\mathrm{Cu}$ leads to more extensive nucleation of $\mathrm{Fe}_{3} \mathrm{O}_{4}$ and $\mathrm{FeC}_{x}$ structures, leading to smaller crystallites, shorter diffusion distances, greater extent of carburization, higher surface areas, and higher hydrocarbon synthesis rates.

Product Evolution during Isothermal Transients of $\mathrm{FeC}_{\mathrm{x}^{-}}$ $\mathrm{Cu}$ and $\mathrm{Fe}_{3} \mathrm{O}_{4}-\mathrm{Cu}$ in Synthesis Gas. The simultaneous formation of $\mathrm{Fe}_{3} \mathrm{O}_{4}$ and $\mathrm{FeC}_{x}$ from $\mathrm{Fe}_{2} \mathrm{O}_{3}$ or $\mathrm{Fe}_{2} \mathrm{O}_{3}-\mathrm{Cu}$ coincides with the incipient formation of gas-phase FTS products, suggesting that either $\mathrm{Fe}_{3} \mathrm{O}_{4}$ or $\mathrm{FeC}_{x}$ may provide active sites for the synthesis of hydrocarbons from $\mathrm{H}_{2} / \mathrm{CO}$ mixtures. In an effort to elucidate the respective roles of these two structures in FTS catalysis, we examined the initial transients in $\mathrm{Cu}$ containing $\mathrm{Fe}_{3} \mathrm{O}_{4}$ and $\mathrm{FeC}_{x}$ samples, synthesized before exposure to synthesis gas at $523 \mathrm{~K}$, but without intervening exposure to ambient air. 


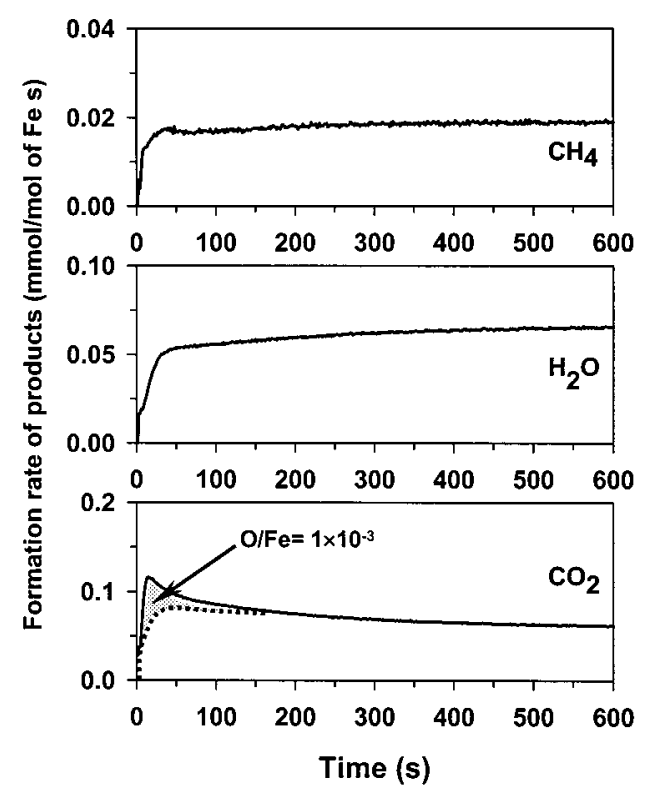

Figure 5. Rates of formation of $\mathrm{CH}_{4}, \mathrm{H}_{2} \mathrm{O}$, and $\mathrm{CO}_{2}$ as a function of time during contact with synthesis gas at $523 \mathrm{~K}$ for prereduced $\mathrm{Fe}_{3} \mathrm{O}_{4}-$ $\mathrm{Cu}\left(0.2 \mathrm{~g}\right.$ sample; $\mathrm{Cu} / \mathrm{Fe}=0.01 ; \mathrm{H}_{2} / \mathrm{CO}=2$, synthesis gas flow rate $=0.268 \mathrm{~mol} / \mathrm{h}$ ). The shaded area in the formation of $\mathrm{CO}_{2}$ is its respective amount formed from the reduction of $\mathrm{Fe}$ oxides upon exposure to synthesis gas; the dashed lines is its expected values from subsequent FTS reactions.

Figure 5 shows initial rates of $\mathrm{CH}_{4}$ formation on $\mathrm{Fe}_{3} \mathrm{O}_{4}-\mathrm{Cu}$ as a function of time in contact with synthesis gas. $\mathrm{CH}_{4}$ formed immediately upon contact with $\mathrm{H}_{2} / \mathrm{CO}$, without the induction period observed on $\mathrm{Fe}_{2} \mathrm{O}_{3}-\mathrm{Cu}$ samples. The rates of $\mathrm{CO}_{2}$ and $\mathrm{H}_{2} \mathrm{O}$ formation were very similar to those expected from the FTS reaction itself, suggesting that $\mathrm{Fe}_{3} \mathrm{O}_{4}-\mathrm{Cu}$ became immediately active in FTS reactions upon contact with synthesis gas. $\mathrm{CH}_{4}$ formation rates reached pseudo-steady-state values within typical turnover times $(\sim 100 \mathrm{~s})$ and without significant removal of lattice oxygen. These data show that either $\mathrm{Fe}_{3} \mathrm{O}_{4}$ is the active phase during FTS reactions or that it converts, within the time required for a FTS turnover, into the required active structure, possibly surface carbide. It appears, therefore, that the assignment of activity to one of these two phases $\left(\mathrm{Fe}_{3} \mathrm{O}_{4}\right.$ or a surface carbide phase derived from it) may not be provable, because their interconversion occurs in the time scale of a reaction turnover. It is inaccurate and possibly misleading to describe $\mathrm{Fe}$ carbides or oxides as the active phases in FischerTropsch synthesis, because these two structures interconvert very rapidly in response to changes in gas phase composition. A working surface seems to be most accurately described as a dynamic phase, surrounding a thermodynamically stable oxide or carbide core, and consisting of oxygen and carbon vacancies, surface oxygen, and carbon atoms occupying lattice positions in the underlying bulk. The composition of the core appears to be irrelevant, except as an underlying matrix supporting these dynamic surface phases. The transient evolution of these surfaces in response to the relative rates of $\mathrm{CO}$ dissociation, carbon and oxygen removal, and hydrocarbon formation makes the relative concentrations of these species sensitively dependent on reactant composition and reaction temperature.

This somewhat disappointing but consistent picture was confirmed by measuring the evolution of products during initial contact of pre-synthesized $\mathrm{FeC}_{x}$ samples with $\mathrm{H}_{2} / \mathrm{CO}$ reactant mixtures. If $\mathrm{Fe}_{3} \mathrm{O}_{4}$ were the exclusive active phase, initial exposure of $\mathrm{FeC}_{x}$ to synthesis gas would lead to an induction period, as the required oxygen atoms are reintroduced into the

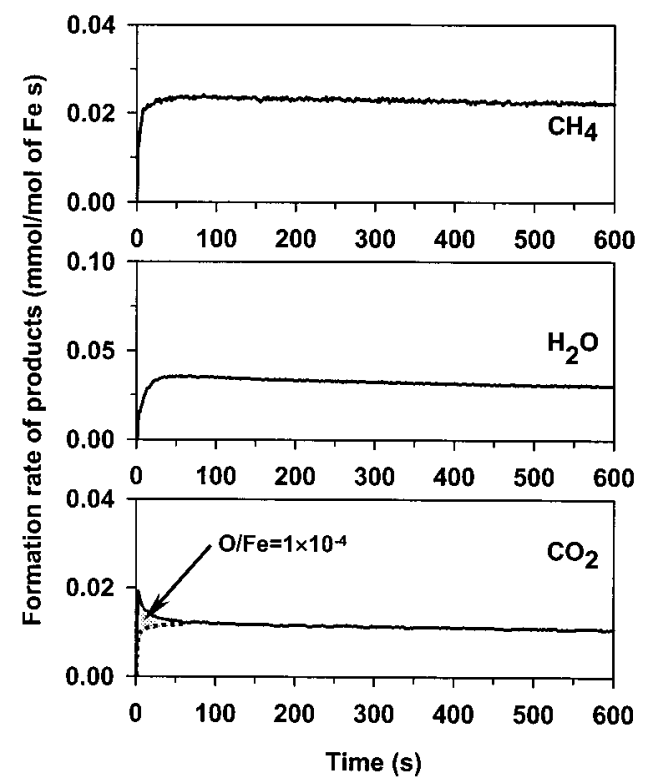

Figure 6. Rates of formation of $\mathrm{CH}_{4}, \mathrm{H}_{2} \mathrm{O}$, and $\mathrm{CO}_{2}$ as a function of time during contact with synthesis gas at $523 \mathrm{~K}$ for pre-carburized $\mathrm{Fe}_{x} \mathrm{C}-\mathrm{Cu}\left(0.2 \mathrm{~g}\right.$ sample; $\mathrm{Cu} / \mathrm{Fe}=0.01 ; \mathrm{H}_{2} / \mathrm{CO}=2$, synthesis gas flow rate $=0.268 \mathrm{~mol} / \mathrm{h}$ ). The shaded area in the formation of $\mathrm{CO}_{2}$ is its respective amount formed due to $\mathrm{O}_{2}$ impurity introduced from the $\mathrm{He}$ carrier gas used during the time period between carbide synthesis and FTS reactions; the dashed lines is its expected values from subsequent FTS reactions.

carbide structure to form $\mathrm{Fe}_{3} \mathrm{O}_{4}$, or to a much lower rate, if carbides remained as inactive or less active $\mathrm{FeC}_{x}$ species. Figure 6 shows that $\mathrm{FeC}_{x}$ samples also reached steady-state FTS rates without an induction period. Steady-state FTS rates are very similar to those obtained using $\mathrm{Fe}_{3} \mathrm{O}_{4}-\mathrm{Cu}$ and $\mathrm{Fe}_{2} \mathrm{O}_{3}-\mathrm{Cu}$ as precursors. Thus, either $\mathrm{FeC}_{x}$ surfaces provide the required FTS active sites or they convert instantaneously, within characteristic turnover times, into the required active structures. The very small amounts of oxygen $\left(\mathrm{O} / \mathrm{Fe}<10^{-4}\right)$ removed from $\mathrm{Fe}$ carbides as $\mathrm{CO}_{2}$ during the first few seconds after exposure to synthesis gas are likely to reflect minor surface contamination of the presynthesized $\mathrm{FeC}_{x}$ by a trace $\mathrm{O}_{2}$ impurity in the $\mathrm{He}$ carrier gas used during the time period elapsed between carbide synthesis and FTS reactions.

Both $\mathrm{Fe}_{3} \mathrm{O}_{4}$ and $\mathrm{FeC}_{x}$ precursors led to the immediate attainment of similar steady-state $\mathrm{CH}_{4}$ formation rates, without requiring any significant changes in the oxygen content of either precursor. Surface layers in either precursor reached a dynamic steady-state structure and composition upon contact with synthesis gas at $523 \mathrm{~K}$. These dynamic rearrangements occur within typical turnover times; they have previously led to apparently contradictory conclusions about the active nature of $\mathrm{Fe}_{3} \mathrm{O}_{4}$ and of various $\mathrm{Fe}$ carbide structures in the FischerTropsch synthesis. The in situ formation of steady-state active structures within characteristic turnover times makes definite conclusions about the active nature of various bulk species not only inaccurate, but inappropriate and potentially misleading.

These results contradict previous conclusions of Datye et al. ${ }^{18,19}$ about the requirement for $\mathrm{FeC}_{x}$ species for FTS activity. Here, we have shown that stoichiometric $\mathrm{Fe}_{2} \mathrm{O}_{3}$, even without $\mathrm{Cu}$ or $\mathrm{K}$ and at mild FTS conditions, becomes active for FTS reactions within turnover times. The absence of hydrocarbon films around $\mathrm{Fe}_{3} \mathrm{O}_{4}$, and even the presence of spurious $\mathrm{Fe}_{3} \mathrm{O}_{4}$ crystallites, must reflect artifacts of the passivation procedures used in these ex-situ measurements. These passivation procedures, even when rigorously carried out, lead to local high 


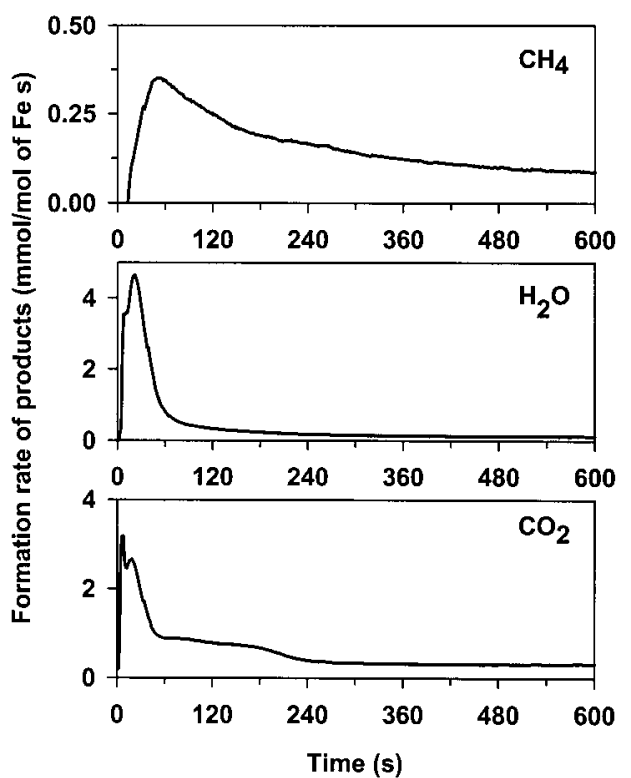

Figure 7. Rates of formation of $\mathrm{CH}_{4}, \mathrm{H}_{2} \mathrm{O}$, and $\mathrm{CO}_{2}$ as a function of time during contact with synthesis gas at $523 \mathrm{~K}$ for $\mathrm{Fe}_{2} \mathrm{O}_{3}-\mathrm{K}-\mathrm{Cu}(0.2$ g sample; $\mathrm{K} / \mathrm{Fe}=0.02, \mathrm{Cu} / \mathrm{Fe}=0.01 ; \mathrm{H}_{2} / \mathrm{CO}=2$, synthesis gas flow rate $=0.268 \mathrm{~mol} / \mathrm{h}$ ).

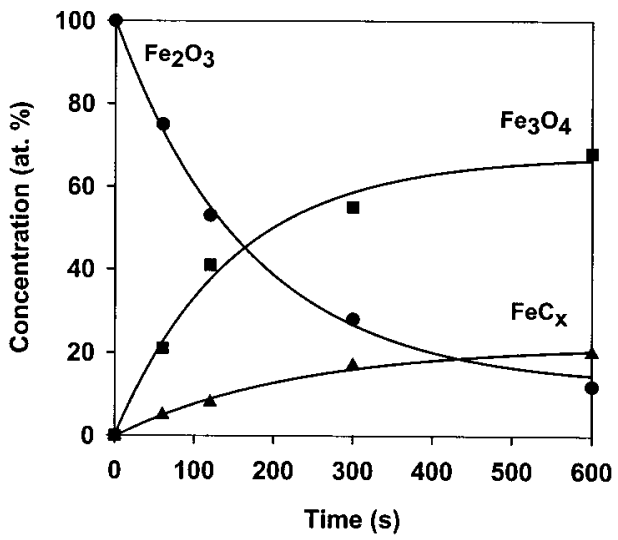

Figure 8. Structural evolution of $\mathrm{Fe}_{2} \mathrm{O}_{3}-\mathrm{K}-\mathrm{Cu}$ with time on stream after exposure to synthesis gas at $523 \mathrm{~K}$ : (@) $\mathrm{Fe}_{2} \mathrm{O}_{3}$, (ם) $\mathrm{Fe}_{3} \mathrm{O}_{4}$, and (ム) $\mathrm{FeC}_{x}\left(1 \mathrm{mg}\right.$ sample; $\mathrm{K} / \mathrm{Fe}=0.02, \mathrm{Cu} / \mathrm{Fe}=0.01 ; \mathrm{H}_{2} / \mathrm{CO}=2$, synthesis gas flow rate $=107 \mathrm{~mol} / \mathrm{mol}$ of $\mathrm{Fe} \mathrm{h}$ ).

temperatures, which can combust the hydrocarbon products formed during FTS and oxidize a fraction of the $\mathrm{FeC}_{x}$ crystallites formed during FTS to $\mathrm{Fe}_{3} \mathrm{O}_{4}$.

Product Evolution and X-ray Absorption Measurements during Isothermal Transients of $\mathrm{Fe}_{2} \mathrm{O}_{3}-\mathrm{Cu}-\mathrm{K}$ in Synthesis Gas. Figure 7 shows $\mathrm{CH}_{4}$ evolution rates on $\mathrm{Fe}_{2} \mathrm{O}_{3}-\mathrm{K}-\mathrm{Cu}(\mathrm{K} /$ $\mathrm{Fe}=0.02, \mathrm{Cu} / \mathrm{Fe}=0.01)$ during initial contact with synthesis gas at $523 \mathrm{~K}$. The rates of $\mathrm{H}_{2} \mathrm{O}$ and $\mathrm{CO}_{2}$ formation on $\mathrm{Fe}_{2} \mathrm{O}_{3}-$ $\mathrm{K}-\mathrm{Cu}$ are very similar to those measured for $\mathrm{Fe}_{2} \mathrm{O}_{3}-\mathrm{Cu}$, except that $\mathrm{CO}$ becomes a more effective reductant than $\mathrm{H}_{2}$ when $\mathrm{K}$ is present. The addition of $\mathrm{K}$ to $\mathrm{Fe}_{2} \mathrm{O}_{3}-\mathrm{Cu}$ samples led to higher rates of $\mathrm{CH}_{4}$ formation after a short induction period, but these rates then decreased with time and reached steady-state values after $\sim 600 \mathrm{~s}$; these steady-state rates are about four times higher than on $\mathrm{Fe}_{2} \mathrm{O}_{3}-\mathrm{Cu}$.

Near-edge Fe X-ray absorption spectra showed that the rate and the extent of carburization in $\mathrm{Fe}_{2} \mathrm{O}_{3}-\mathrm{K}-\mathrm{Cu}$ (Figure 8) are even higher than on $\mathrm{Fe}_{2} \mathrm{O}_{3}-\mathrm{Cu}$ (Figure 4). The promotional effects of $\mathrm{K}$ on the rate and extent of carburization are similar to those observed when $\mathrm{Cu}$ was added to $\mathrm{Fe}_{2} \mathrm{O}_{3}$ precursors. Apparently $\mathrm{K}$, as carbonates, ${ }^{17}$ also provides activation sites for
TABLE 1: Surface Area and CO Chemisorption Results after 1 h FTS Reactions; Fe Carbide Concentrations Obtained from in Situ XAS, and $\mathrm{CH}_{4}$ Formation Rates from Transient Experiments, on Unpromoted and Promoted $\mathrm{Fe}_{2} \mathrm{O}_{3}(\mathrm{~K} / \mathrm{Fe}=0.02, \mathrm{Cu} / \mathrm{Fe}=0.01)$ after $5 \mathrm{~h}$ FTS Reactions

\begin{tabular}{llcc}
\hline \multicolumn{1}{c}{ oxide precursor } & $\mathrm{Fe}_{2} \mathrm{O}_{3}$ & $\mathrm{Fe}_{2} \mathrm{O}_{3}-\mathrm{Cu}$ & $\mathrm{Fe}_{2} \mathrm{O}_{3}-\mathrm{K}-\mathrm{Cu}$ \\
\hline $\begin{array}{l}\text { surface area after reaction } \\
\left(\mathrm{m}^{2} / \mathrm{g}\right)\end{array}$ & 13 & 17 & 23 \\
$\begin{array}{c}\text { amount of } \mathrm{CO} \text { chemisorbed } \\
\text { after reaction }(\mathrm{mmol} / \mathrm{mol} \text { of } \mathrm{Fe})\end{array}$ & 8.1 & 14 & 39 \\
$\begin{array}{c}\text { steady-state } \mathrm{FeC}_{x} \\
\quad \text { concentration }\end{array}$ (at. \%) & 29 & 34 & 88 \\
steady-state $\mathrm{CH}_{4}$ formation & 0.061 & 0.070 & 0.19
\end{tabular}
rate $^{b}$ (mmol/g-atom Fe s)

${ }^{a} \mathrm{FeC}_{x}$ concentration measured after exposure to synthesis gas at 523 $\mathrm{K}$ for $5 \mathrm{~h}\left(1 \mathrm{mg}\right.$ sample; $\mathrm{H}_{2} / \mathrm{CO}=2$, synthesis gas flow rate $=107 \mathrm{~mol} /$ mol of $\mathrm{Fe} \mathrm{h}) .{ }^{b} \mathrm{CH}_{4}$ formation rates measured after exposure to synthesis gas at $523 \mathrm{~K}$ for $5 \mathrm{~h}\left(0.2 \mathrm{~g}\right.$ sample; $\mathrm{H}_{2} / \mathrm{CO}=2$, synthesis gas flow rate $=0.268 \mathrm{~mol} / \mathrm{h}$ ).

the synthesis gas reductant and the nucleation sites required for the formation of a larger number of smaller crystallites than in the absence of $\mathrm{K}$ or $\mathrm{Cu}$ promoters. The conclusions reached from these measurements on $\mathrm{Fe}_{2} \mathrm{O}_{3}-\mathrm{K}-\mathrm{Cu}$ are identical to those reached from similar experiments on $\mathrm{Fe}_{2} \mathrm{O}_{3}-\mathrm{Cu}$ precursors.

Promotional Effects of $\mathrm{K}$ and $\mathrm{Cu}$ on Fischer-Tropsch Synthesis Rates. BET surface areas and CO chemisorption uptakes were measured after FTS reactions for $1 \mathrm{~h}$ in order to confirm that $\mathrm{K}$ and $\mathrm{Cu}$ promoters led to the formation of smaller Fe carbide crystallites $\left(\mathrm{H}_{2} / \mathrm{CO}=2,523 \mathrm{~K}\right.$; Table 1$)$. BET surface areas were higher on samples containing $\mathrm{K}$ and $\mathrm{Cu}$, clearly indicating the formation of smaller crystallites in activated samples. $\mathrm{CO}$ chemisorption uptakes were also higher on $\mathrm{Fe}_{2} \mathrm{O}_{3}-\mathrm{Cu}$ and on $\mathrm{Fe}_{2} \mathrm{O}_{3}-\mathrm{K}-\mathrm{Cu}$ than on unpromoted $\mathrm{Fe}_{2} \mathrm{O}_{3}$. The density of binding sites available for $\mathrm{CO}$ chemisorption was higher on $\mathrm{Cu}$-containing samples and reached the highest value when both $\mathrm{K}$ and $\mathrm{Cu}$ were present. This is consistent with the proposal that $\mathrm{K}$ and $\mathrm{Cu}$ promoters lead to the nucleation of a larger number of smaller crystallites with higher surface areas during the conversion of $\mathrm{Fe}_{2} \mathrm{O}_{3}$ precursors to $\mathrm{Fe}_{3} \mathrm{O}_{4}$ and $\mathrm{FeC}_{x}$. FTS rates increased proportionally with the observed increase in the $\mathrm{FeC}_{x}$ content of steady-state catalysts and with the measured increase in $\mathrm{CO}$ chemisorption uptakes after reaction. These consistent trends among the surface area, the $\mathrm{CO}$ chemisorption site density, the extent of carburization, and the hydrocarbon synthesis rates indicate that the effect of $\mathrm{K}$ and $\mathrm{Cu}$ is indeed to promote the formation of smaller Fe carbide crystallites. These smaller crystallites in turn lead to a larger number of active sites for $\mathrm{CO}$ chemisorption, for the activation of synthesis gas during the initial structural changes of the $\mathrm{Fe}_{2} \mathrm{O}_{3}$ precursors, and thus for FTS reactions. The resulting shorter distances for oxygen transport through solid particles also lead to the more extensive carburization of $\mathrm{Fe}_{2} \mathrm{O}_{3}$ crystallites containing $\mathrm{Cu}$ and/or $\mathrm{K}$.

These results have led to a consistent picture of the structural evolution of these materials and of its catalytic implications (Figure 9). This picture may lack some of the detailed morphological features, but it is consistent with the findings described above and with the known chemistry of oxide-carbide transformations. The shell-core structure shown schematically in Figure 9a is used to describe the reduction and carburization of $\mathrm{Fe}_{2} \mathrm{O}_{3}$ precursor crystallites in synthesis gas. Upon contact with $\mathrm{H}_{2} / \mathrm{CO}$ at sufficiently high temperatures, lattice oxygen atoms near $\mathrm{Fe}_{2} \mathrm{O}_{3}$ surfaces are removed by reaction with $\mathrm{H}_{2}$ or $\mathrm{CO}$, to form oxygen-deficient $\mathrm{Fe}_{2} \mathrm{O}_{3}$. As the concentration of oxygen vacancies in $\mathrm{Fe}_{2} \mathrm{O}_{3}$ reaches a critical value, a new $\mathrm{Fe}_{3} \mathrm{O}_{4}$ 
(a)

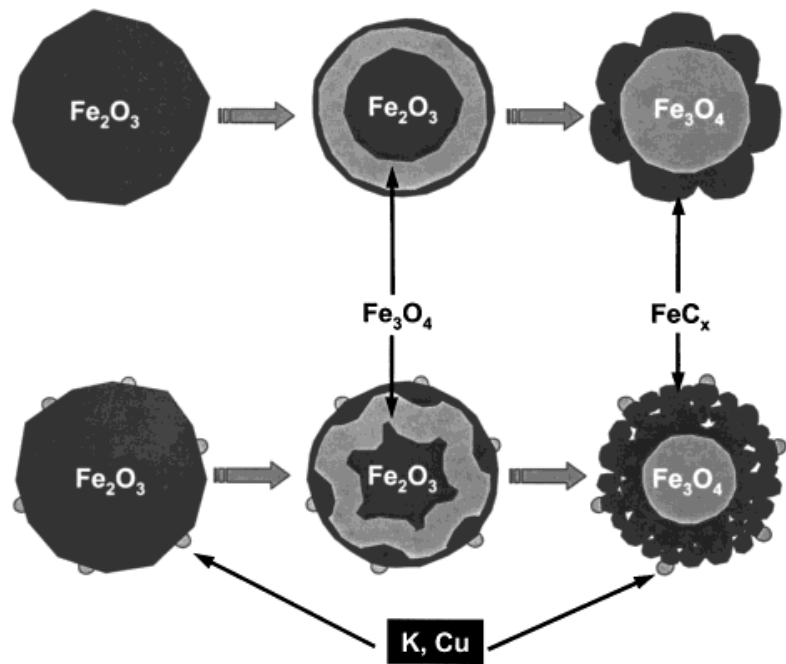

Figure 9. Shell-core model describing the structural evolution of the particles of (a) $\mathrm{Fe}_{2} \mathrm{O}_{3}$ and (b) $\mathrm{K}$ - or $\mathrm{Cu}$-containing $\mathrm{Fe}_{2} \mathrm{O}_{3}$ after exposure to synthesis gas.

structure nucleates at the most oxygen-deficient regions, which tend to reside near $\mathrm{Fe}_{2} \mathrm{O}_{3}$ surfaces. The skeletal density of $\mathrm{Fe}_{3} \mathrm{O}_{4}$ differs only slightly from that of $\mathrm{Fe}_{2} \mathrm{O}_{3}$, but an incipient lattice mismatch can lead to the nucleation of $\mathrm{Fe}_{3} \mathrm{O}_{4}$ grains at $\mathrm{Fe}_{2} \mathrm{O}_{3}$ surfaces. This will likely occur uniformly and as a contiguous phase in unpromoted $\mathrm{Fe}_{2} \mathrm{O}_{3}$, which lack specific locations with higher oxygen deficiency. In contrast, the presence of $\mathrm{Cu}$ or $\mathrm{K}$ species at specific locations on $\mathrm{Fe}_{2} \mathrm{O}_{3}$ surfaces (Figure 9b), and their role in the activation of the $\mathrm{H}_{2}$ and $\mathrm{CO}$ reactants, can lead to selected regions with higher oxygen deficiency and to the preferential nucleation of a new phase at multiple locations on the surface of an $\mathrm{Fe}_{2} \mathrm{O}_{3}$ crystallite. The nucleation of $\mathrm{Fe}_{3} \mathrm{O}_{4}$ is immediately followed by its carburization, which is likely to involve the continuing removal of lattice oxygen and the formation of oxygen vacancies leading to dissociation of $\mathrm{CO}$ and to the formation of carbon and oxygen species, which eventually react to form hydrocarbons and $\mathrm{H}_{2} \mathrm{O}$ and $\mathrm{CO}_{2}$, respectively, in the Fischer-Tropsch synthesis. This $\mathrm{CO}$ dissociation step leads both to progressive carburization and to FTS turnovers, thus explaining the coincident evolution of an increasingly carbided sample and of FTS catalytic activity, without implying a causal relationship between the two. As the thermodynamically favored conversion of $\mathrm{Fe}_{3} \mathrm{O}_{4}$ to $\mathrm{FeC}_{x}$ continues, a nearly uniform $\mathrm{FeC}_{x}$ shell on pure $\mathrm{Fe}_{2} \mathrm{O}_{3}$, or a patchy carbide phase on promoted $\mathrm{Fe}_{2} \mathrm{O}_{3}$, will separate from the unconverted bulk, because of significant differences in the skeletal densities of carbide and oxide structures $\left(7.7 \mathrm{~g} / \mathrm{cm}^{3}\right.$ for $\mathrm{Fe}_{3} \mathrm{C} ; 5.2 \mathrm{~g} / \mathrm{cm}^{3}$ for $\mathrm{Fe}_{3} \mathrm{O}_{4}$ ), and lead to the formation of $\mathrm{Fe}$ carbide "islands" scattered on the surface of the residual $\mathrm{Fe}_{3} \mathrm{O}_{4}$ core (Figure 9a). On K- or Cu-containing $\mathrm{Fe}_{2} \mathrm{O}_{3}$ (Figure 9b), the higher reduction and carburization rates in $\mathrm{Fe}_{2} \mathrm{O}_{3}$ regions near these promoters ${ }^{2}$ leads to local high densities of oxygen vacancies, of $\mathrm{Fe}_{3} \mathrm{O}_{4}$ nuclei, and of carbide patches in such regions. These rapid multiple nucleation processes lead to more fractured and accessible structures, with a higher surface area, and a shorter diffusion distance for the gradual removal of the oxygen atoms retained within the remaining oxide cores. The resulting higher surface areas provide a larger number of sites for $\mathrm{CO}$ chemisorption and for FTS turnovers, as found in this study.

\section{Conclusions}

The removal of a small fraction of the lattice oxygen atoms in $\mathrm{Fe}_{2} \mathrm{O}_{3}$, corresponding to $\sim 1$ equivalent monolayer, is required for the formation of active sites for the Fischer-Tropsch synthesis. After these initial reduction processes, the formation of additional amounts of $\mathrm{Fe}_{3} \mathrm{O}_{4}$ and its rapid conversion to $\mathrm{FeC}_{x}$ occur without significant changes in FTS rate or selectivity. Steady-state FTS reaction rates require only the incipient conversion of the surface layers of Fe oxides to a dynamic active structure, which consists of $\mathrm{FeC}_{x}$ layers, with a catalytically irrelevant Fe oxide core, and containing a steady-state surface coverage of carbon or oxygen vacancies. Active structures form from $\mathrm{Fe}$ oxide precursors within characteristic turnover tines and without detectable changes in oxygen content of presynthesized $\mathrm{Cu}$-containing $\mathrm{Fe}_{3} \mathrm{O}_{4}$ or $\mathrm{FeC}_{x}$ upon exposure to synthesis gas at $523 \mathrm{~K}$. The facile interconversion of $\mathrm{Fe}_{3} \mathrm{O}_{4}$ and $\mathrm{FeC}_{x}$ during FTS occurs as the result of elementary steps involved in FTS and makes the assignment of catalytic activity to either of these two phases neither appropriate nor kinetically relevant. The presence of $\mathrm{K}$ and $\mathrm{Cu}$ in $\mathrm{Fe}_{2} \mathrm{O}_{3}$ precursors leads to the formation of a larger number of nucleation sites for $\mathrm{Fe}_{3} \mathrm{O}_{4}$ and $\mathrm{FeC}_{x}$ structures and to the ultimate formation of smaller crystallites. These smaller crystallites lead, in turn, to shorter diffusion paths for the conversion of the $\mathrm{Fe}_{3} \mathrm{O}_{4}$ core to $\mathrm{FeC}_{x}$, and to a larger number of sites for $\mathrm{CO}$ chemisorption and for the Fischer-Tropsch synthesis reactions.

Acknowledgment. This work was supported by the U. S. Department of Energy (DOE) under Contract No. DE-FC2698FT40308. The X-ray absorption data were collected at the Stanford Synchrotron Radiation Laboratory (SSRL), which is operated by the Department of Energy (DOE), Office of Basic Energy Sciences under contract DE-ACO3-76SF00515.

\section{References and Notes}

(1) Soled, S. L.; Iglesia, E.; Miseo, S.; DeRites, B. A.; Fiato, R. A. Top. Catal. 1995, 2, 193

(2) Li, S.; Li, A.; Krishnamoorthy, S.; Iglesia, E. Catal. Lett., in press.

(3) Li, S.; Meitzner, G. D.; Iglesia, E. J. Phys. Chem. B 2001, 105, 5743.

(4) Biloen, P.; Helle, J. N.; Sachtler, W. J. Catal. 1979, 58, 95.

(5) O'Brien, R. J.; Xu, L.; Spicer, R. L.; Bao, S.; Milburn, D. R.; Davis, B. H. Catal. Today 1997, 36, 325

(6) Rankin, J. L.; Bartholomew, C. H. J. Catal. 1998, 100, 526.

(7) Rankin, J. L.; Bartholomew, C. H. J. Catal. 1998, 100, 533.

(8) Li, S.; Meitzner, G. D.; Iglesia, E., unpublished results.

(9) Li, S.; Krishnamoorthy, S.; Li, A.; Meitzner, G. D.; Iglesia, E., submitted to $J$. Catal.

(10) Handbook of Chemistry and Physics, 75th ed.; Lide, D. R., Frederikse, H. P. R., Ed.; The Chemical Rubber Company Press: Boca Raton, 1994.

(11) Bearden, A.; Burr, A. F. Rev. Mod. Phys. 1967, 39, 125.

(12) Ressler, T. J. Synchrotron Rad. 1998, 5, 118.

(13) WinXAS97 is an XAS data analysis program for PCs running MSWindows by Thorsten Ressler (http://ourworld.compuserve.com/homepages/ t_ressler)

(14) Malinowski, E. R.; Howery, D. G. In Factor Analysis in Chemistry; John Wiley \& Sons: New York, 1981.

(15) Meitzner, G. D.; Huang, E. S. Fresenius J. Anal. Chem. 1992, 342, 61

(16) Oyama, S. T.; Schlatter, J. C.; Metcalfe, J. E., III; Lambert, J. M., Jr. Ind. Eng. Chem. Res. 1988, 27, 1639.

(17) Li, S.; Meitzner, G. D.; Iglesia, E., unpublished results.

(18) Mansker, L. D.; Jin, Y.; Burker, D. B.; Datye, A. K. Appl. Catal. A: General 1999, 186, 277

(19) Shroff, M. D.; Kalakkad, D. S.; Coulter, K. E.; Kohler, S. D.; Harrington, M. S.; Jackson, N. B.; Sault, A. G.; Datye, A. K. J. Catal. $1995,156,185$ 